\title{
Con profunda gratitud
}

This book has been a collective effort spanning more than half a decade, and we have many people and organizations to thank. First and foremost, of course, we thank Gloria Anzaldúa, who has been such a source of guidance, inspiration, and brilliance to us both. We are deeply grateful to every one of the contributors of this collection. Thank you, fellow writers, for your personal and intellectual vulnerability, for "risking the personal" so thoroughly! Thank you for your outpouring of hard work and love while staying engaged from beginning to end of this (long!) process. We appreciate your prompt replies and diligent work in response to our requests for revision and your great patience as we brought this book into the world.

We're grateful to all the people who have helped to preserve Gloria Evangelina Anzaldúa's words and work. We especially thank Hilda Anzaldúa, Kit Quan, and Irene Reti for their firm commitment to making the Anzaldúa archives a reality. We express our sincere gratitude to Ann Hartness, former head librarian of the Nettie Lee Benson Latin American Collection; Margo Gutiérrez, interim head librarian at the Nettie Lee Benson Latin American Collection; Christian Kelleher, archivist at the Benson Collection; and José Limón, director of the Center for Mexican American Studies, for their various roles in the acquisition of the archive of Gloria Evangelina Anzaldúa, now housed at the Benson Latin American Collection at the University of Texas at Austin. We also thank Christian Kelleher for his ongoing support of archival research on Anzaldúa and for his assistance with our queries as we prepared this book. Thank you, Christian; your support has been priceless. Our special admiration, respect, and gratitude go to Norma E. Cantú and Sonia 
Saldívar-Hull at the University of Texas at San Antonio for being hardworking maestras actively creating vibrant intellectual and spiritual communities and families committed to nurturing the priceless contributions of Gloria Anzaldúa and creating future generations of Anzaldúan scholars.

The University of Texas Press has been the ideal home for this book. Our sincere gratitude goes to Theresa May, assistant director and editorin-chief, for her encouragement and support of this project. We are also grateful to Sarah Hudgens for her support, kindness, and help in the manuscript preparation process. We thank Lynne Chapman, manuscript editor, for her assistance in moving our manuscript through the publication process, and we thank Tana Silva for her superb copyediting skills. We're extremely grateful to the external reviewers of this manuscript, Edith Morris-Vasquez and Layli Phillips Maparyan, whose excitement for this project re-energized us and whose comments inspired us in useful and valuable ways to re-envision the introduction. We know that reading manuscripts can be a time-consuming job, and we very much appreciate the care you took with Bridging.

We would like to express our gratitude to Dr. Domino Perez, Acting Director, and Natasha Saldaña, Academic Advisor, of the Center for Mexican American Studies for their kindness and support as we worked on the book cover. We are also grateful to Annie Valva for allowing us to use her photograph on the cover.

The idea for this book has its source in the two-day tribute for Gloria E. Anzaldúa that took place in Austin in October 2004. With special cariño, respect, and gratitude we acknowledge all the people (students, professors, community-based activists, and artists, among other professionals) who through their affiliation with the University of Texas at Austin and ALLGO (Austin Latina/Latino Lesbian, Gay, Bisexual, \& Transgender Organization) actively participated in organizing the event. Thanks to each of you for the inspiration and the original flame giving life to the idea of exploring ways to build and expand on Gloria Anzaldúa's influential scholarship.

Together, we, AnaLouise Keating and Gloria González-López, wish to acknowledge each other for mutual creativity, inspiration, and support in the process of giving birth to this book. Each of us contributed equally to the development of this collection. The order of authorship in this book and the introduction is intended to acknowledge Keating's place in the intellectual genealogy of Anzaldúan studies. 


\section{AnaLouise Keating}

Co-editing a book is a big responsibility; in some ways, it's even more difficult than simply editing a book on one's own. First thanks go to my co-editor, Gloria González-López, for initiating this book, for being so touched by Gloria Evangelina Anzaldúa and her words. Comadre: When I heard your beautiful, loving, insightful discussion of nepantla/ nepantleras at the October 2004 Anzaldúa tribute in Austin, I knew you would be a trustworthy co-editor and a careful interpreter of Anzaldúa's words; my faith has been entirely well placed and accurate. As you know, the academy can be an inhospitable place; it's so great to connect with other passionate, holistic scholars. To borrow Anzaldúa's words, Tú eres una nepantlera, una alma afin. I'm grateful for my job at Texas Woman's University, where Anzaldúa did her freshman year of college back in the 1960s (Is that a coincidence, or what?!); for Gail Orlando, whose timesaving office assistance is irreplaceable; and for my awesome students, whose excitement and appreciation for Anzaldúa and transformation consistently energize me. Thanks to Claire L. Sahlin, who is the best department chair I've ever encountered as well as a terrific colleague and friend. Thanks to Glenda Lehrmann and the FIRST (Faculty Information and Research Support Team) staff at Texas Woman's University for assistance with reference material. Thanks to Nadine Barrett, Kavitha Koshy, Doreen Watson, and the other mujeres of BRIDGES for encouraging me to attend the Anzaldúa tribute in Austin and for offering such helpful, nourishing feedback and support. I don't even have the words to express my profound gratitude to my family, especially Eddy Lynton and Jamitrice Keating-Lynton, for your continued patience, understanding, encouragement, generosity, and presence; you are the best parts of my life. Really. For as long as you have known me, Gloria Anzaldúa has been present in our lives, and you have had to share me-first with my friend and writing comadre, the flesh-and-blood person, and now with her work. And finally, I thank the orishas, espíritus, and ancestors for guiding me, whispering words of encouragement that nourish my body/heart/mind/spirit and inspire my vision.

\section{Gloria González-López}

Working on this book has represented a collective labor of love that has only been possible with the invaluable presence and support of 
many wonderful colleagues and friends. First, I am deeply grateful to AnaLouise Keating for embarking on this project with me. It has been an honor to share this journey with you. I have learned so much from you, and I am forever grateful for this priceless opportunity and privilege-gracias, comadre, de todo corazón. I express my profound respect and gratitude to Amalia Anzaldúa and Hilda Anzaldúa for their kindness and generosity while sharing and teaching me so much about Gloria Evangelina Anzaldúa's life during a visit to the Rio Grande Valley in 2004. I am especially grateful to the University of Texas at Austin for being a source of inspiration while validating the importance of Gloria Anzaldúa's intellectual legacy. I would like to express my special appreciation to Sue Heinzelman, director of the Center for Women's and Gender Studies, and Christine Williams, professor of sociology at the University of Texas at Austin, for being terrific and supportive colleagues, mentors, and friends, for always stimulating and validating the importance of my feminist thinking and intellectual curiosity within and across disciplines. Y a Pierrette Hondagneu-Sotelo expreso mi gratitud por ser la siempre presente inspiración.

A mi madre, como siempre no tengo palabras para expresar mi amor y gratitud por el regalo de la vida y amor maternal que no conoce límites, y a mi padre por estar ahora aún más presente en la ausencia; a mis hermanas y hermanos con el cariño y gratitud de toda la vida. A Jodi expreso mi más sincero amor y gratitud por su inquebrantable solidaridad y apoyo, y por su generosidad y bondad amorosa, siempre inagotables, durante este laborioso proyecto y en tiempos difíciles. Por siempre, gracias.

I express my limitless love and gratitude to my most precious and highest teachers, mis maestros y guías espirituales, Kirti Tsenshab Rinpoche and Lama Thubten Zopa Rinpoche, for their sacred presence and life-transforming blessings and teachings. May whatever contribution I have made in the process of working on this book become endlessly beneficial to others. 


\section{Bridging}


THIS PAGE INTENTIONALLY LEFT BLANK 